\title{
ANALISIS BAURAN PEMASARAN BERAS INSTANT SEBAGAI PRODUK BARU DI PASAR KOTA BENGKULU
}

\author{
Ivo Imtar Pramudita1, Miftahul Janah², Fitriana Permata Sari ${ }^{3}$, Putri Suci Asriani ${ }^{4}$, \\ dan Bonodikun ${ }^{5}$ \\ ${ }^{1}$ Mahasiswa S1 Jurusan Sosek Pertanian FP Universitas Bengkulu \\ ${ }^{2}$ Staf Lab. Sosek Pertanian FP Universitas Bengkulu \\ ${ }^{3}$ Staf Lab. Sosek Pertanian FP Universitas Bengkulu dan Mahasiswa S2 Magister Agribisnis FP \\ Universitas Bengkulu \\ ${ }^{4}$ Staf Pengajar Jurusan Sosek Pertanian FP Universitas Bengkulu \\ ${ }^{5}$ Staf Pengajar Jurusan Teknologi Pertanian FP Universitas Bengkulu \\ Email: ivoimtarpramudita4@gmail.com
}

\begin{abstract}
ABSTRAK
Ubi kayu, ubi jalar, dan jagung merupakan sumberdaya lokal Bengkulu yang potensial untuk dikembangkan sebagai produk inovatif berupa beras instan sumber karbohidrat alternatif (Asriani, 2016). Beras instan ubi kayu, ubi jalar, dan jagung sebagai produk baru tidak selalu dapat langsung diterima oleh calon konsumennya, dalam pengembangannya perlu dikaji bagaimana bauran pemasaran beras instan untuk melihat pada posisi manakah beras instan pada saat ini. Dengan mengetahui posisi tersebut, akan memberikan kemudahan dalam penyusunan strategi pemasaran beras instan agar dapat diterima dengan baik oleh calon konsumennya. Analisis Bauran Pemasaran harus terus dilakukan, salah satunya adalah dengan didasarkan pada 4P (Product, Price, Promotion, Place) terhadap beras instan. Melalui hasil analisis Matrik Internal Eksternal (IE) secara deskriptif kualitatif Beras Instan berada pada sel I dengan total skor faktor internal sebesar 3,611549 dan faktor eksternal sebesar 3,110227 yang menggambarkan bahwa keadaan Beras Instan pada saat ini sedang tumbuh dan membangun (Grow end build), yaitu beras instan berada pada tahap pengembangan produk. Hal tersebut didukung dengan adanya kemudahan beras instan dalam pengolahannya menjadi nasi, praktis dan sehat serta terus dilakukannya pengenalan-pengenalan beras instan kepada calon konsumen.
\end{abstract}

Kata kunci: beras instan, sumber karbohidrat, bauran pemasaran, matrik IE

\begin{abstract}
Cassava, sweet potatoes, and corn are the potential local resources of Bengkulu to be developed as innovative products of instant rice of alternative carbohydrate sources (Asriani, 2016). Instant rice cassava, sweet potato, and corn as a new product cannot always be directly accepted by prospective customers, in its development need to be studied how marketing mix of instant rice to see at which position instant rice at this time. By knowing the position, will provide convenience in the preparation of instant rice marketing strategy to be well received by prospective customers. Marketing mix analysis should continue, one of which is based on 4P (Product, Price, Promotion, Place) on instant rice. Through the analysis of External Internal External (IE) is qualitative descriptive Instant Rice resides in cell I with total internal factor score of 3.611549 and external factor of 3.110227 which illustrates that the state of Instant Rice is currently growing and building (Grow end Build), ie. instant rice is at the stage of product development. This is supported by the ease of instant rice in processing into rice, practical and healthy and continuous introduction of instant rice introductions to prospective customers.
\end{abstract}

Keywords: instant rice, carbohydrate source, marketing mix, IE matrix 


\section{PENDAHULUAN}

Ubi kayu, ubi jalar, dan jagung merupakan sumberdaya lokal Bengkulu yang potensial untuk dikembangkan sebagai produk inovatif berupa beras instan sumber karbohidrat alternatif (Asriani, 2016). Beras Instan merupakan salah satu prodak baru yang ditawarkan di Kota Bengkulu dengan tujuan memberikan trobosan baru dan variasi kepada masyarakat dalam mengkonsumsi sumber karbohidrat. Beras instan memanfaatkan bahan pangan lokal yang melimpah di Provinsi Bengkulu berupa ubi kayu, ubi jalar dan jagung. Hal ini dapat diartikan sebagai peningkatan suatu produk melalui inovasi yang dilakukan. Namun, beras instan ini tidak begitu saja dapat diterima dengan mudah oleh calon konsumen. Dikarenakan calon konsumen belum terbiasa mengkonsumsi dari ketiga komoditi yang telah dikembangkan menjadi beras instan. Berangkat dari fenomena tersebut, maka dilakukanlah analisis bauran pemasaran untuk mengembangkan produk Beras Instan ini melalui konsep 4P/marketing mix (bauran pemasaran) yang terdiri dari product (produk), price (harga), promotion (tempat), place (tempat) (Kotler dan Keller, 2006 dalam Selmi, 2016).

\section{METODE PENELITIAN}

Jenis data yang digunakan yaitu data primer dan sekunder. Data primer diperoleh melalui wawancara langsung dengan calon konsumen, dengan mengajukan daftar pertanyaan terstruktur yang telah melalui uji validitas dan realibilitas. Sedangkan data sekunder diperoleh dari instansi-instansi yang terkait. Analisis yang digunakan dengan matriks Internal Eksternal (Matriks IE). Kerangka pemikiran pada penelitian ini dapat dilihat pada Gambar 1.

Beras instan yang merupakan produk baru hasil inovasi dari komoditi ubi kayu, ubi jalar dan jagung yang dikembangkan di Kota Bengkulu ini dianalisis menggunakan bauran pemasaran. Bauran pemasaran ini terdiri dari 4 P yaitu Product, Price, Promotion and Place. Setelah mendapatkan hasil dari bauran pemasaran tersebut, maka barulah diketahui posisi beras instan pada saat ini. Apakah sudah dapat diterima oleh calon konsumen atau belum.

\section{HASIL DAN PEMBAHASAN}

Lingkungan Internal. Lingkungan internal adalah segala sesuatu yang dimiliki oleh beras instan, yang berupa kekuatan dan kelemahan dari beras instan itu sendiri (Salastina, 2010). Faktor internal yang berpengaruh terhadap atribut beras instan pada calon konsumen di Kota Bengkulu dalam bauran pemasaran, yaitu sebagai berikut : 1) Atribut produk terdiri dari rasa nasi, kepulenan nasi, aroma nasi, kemasan, volume, merek, makanan yang sehat dan aman bagi keluarga (tidak menggunakan bahan pengawet dan 100\% bahan asli).

2) Atribut harga terdiri dari keterjangkauan harga.

3) Atribut promosi terdiri dari praktis dan mudah disimpan dan mudah diolah.

4) Atribut tempat terdiri dari akses yang mudah dijangkau

Lingkupan Eksternal. Lingkungan eksternal adalah faktor-faktor yang letaknya berada di luar dan terlepas dari beras instan. Dimana lingkungan eksternal ini dapat memberikan kesempatan bagi beras instan untuk maju, bahkan dapat menjadi hambatan dan ancaman pada beras instan untuk maju (Salastina, 2010). Faktor eksternal yang berpengaruh terhadap atribut beras instan pada calon konsumen di Kota Bengkulu dalam bauran pamasaran, yaitu sebagai berikut :

1) Atribut produk terdiri dari beras instan belum disukai oleh calon konsumen, beras instan kurang dibutuhkan setiap saat, keinginan calon konsumen untuk mengganti beras Oryza sativa ke beras instan.

2) Atribut harga terdiri dari banyak produk subtitusi yang harganya lebih terjangkau.

3) Atribut promosi terdiri dari promosi yang kurang gencar.

4) Atribut tempat terdiri dari kemudahan calon konsumen untuk menjangkau keberadaan beras instan.

Evaluasi Faktor Internal dan

Eksternal. Evaluasi faktor-faktor yang mempengaruhi bauran pemasaran beras instan di Kota Bengkulu, diperoleh hasil analisis yang terdiri dari Internal Factor Evaluation (IFE) dan Eksternal Factor Evaluation (EFE). Matriks evaluasi faktor internal bauran pemasaran beras instan, disajikan dalam Tabel 1 berikut.

Berdasarkan Tabel 1. Diketahui skor tertinggi adalah 0,496901 pada kemasan. 
Sedangkan skor terendah adalah 0,205352 pada keterjangkauan harga. Total skor matriks IFE sebesar 3,611549, hal ini menunjukkan bahwa kondisi internal berada pada daerah kuat yang berarti kekuatan yang dimiliki dapat mengatasi kelemahan dengan baik. Dengan artian bahwa, atribut produk memiliki kekuatan untuk menutupi kelemahan atribut harga yang masih tergolong tinggi.

Pada Tabel 2 juga menunjukkan bahwa keinginan calon konsumen untuk mengganti beras Oryza sativa ke beras instan terletak pada posisi terendah yaitu dengan skor 0,184091 . Sedangkan total skor pada faktor eksternal adalah 3,110227 maka hal ini menunjukkan bahwa kondisi eksternal berada pada daerah tertinggi yaitu pengembang usaha beras instan sangat baik dalam merespon peluang dan meminimalisasi ancaman. Walaupun calon konsumen masih sulit untuk berpindah pada beras instan sebagai makanan pokok sehari-hari. Total skor yang hampir mendekati 4,0 maka mengindikasikan bahwa sebuah beras instan merespon secara sangat baik peluang dan ancaman yang ada pada lingkungan internal beras instan. Dengan kata lain, strategi beras instan secara efektif mampu menarik keuntungan dari peluang yang ada dan meminimalkan pengaruh negatif potensial dari ancaman (David, 2011).

Hasil analisis eksternal (Tabel 2) menunjukkan bahwa beras instan belum disukai oleh calon konsumen dan kemudahan calon konsumen untuk menjangkau keberadaan beras instan berada pada skor yang sama dan tertinggi yaitu sebesar 0,820455 . Matriks evaluasi faktor eksternal bauran pemasaran beras instan, disajikan dalam Tabel 2.

\section{Analisis Matriks Internal Eksternal}

(IE). Cara untuk memperoleh matriks IE yaitu dari hasil analisis faktor internal dan eksternal beras instan yang merupakan penggabungan antara total skor pada matriks EFE dan IFE. Berdasarkan matriks IE yang `diperoleh dari nilai tertimbang pada matriks IFE dan EFE. Nilai tertimbang sebesar 3,611549 diperoleh dari matriks IFE, yang menjelaskan bahwa bauran pemasaran beras instan mempunyai posisi internal yang kuat. Sedangkan nilai tertimbang EFE sebesar 3,110227 menjelaskan bahwa bauran pemasaran beras instan juga mempunyai posisi eksternal yang kuat. Maka hal ini menunjukkan beras instan sangat baik dalam merespon peluang dan meminimalisir ancaman. Total matriks IFE dan EFE kemudian dipetakan dalam matriks IE, sehingga diketahui posisi beras instan pada saat ini yang akan ditunjukkan pada gambar 2 .

Pada analisis Matrik Internal Eksternal (IE) yang dapat dilihat pada Gambar 2, yang menunjukkan bahwa posisi pemasaran beras instan di Kota Bengkulu terletak pada sel I yaitu tahap tumbuh dan membangun (Grow end build) (Anonim, 2007). Dimana sel I tersebut menggambarkan kemampuan beras instan dalam merespon lingkungan internal dan eksternalnya masih dalam maka akan diketahui posisi beras instan pada saat ini. Sesuai dengan yang dijelaskan oleh Risma (2014) dalam Sugiharta (2016) bahwa, Sel I, II atau IV dapat disebut tumbuh dan bina. Sehingga strategi yang harus diterapkan yaitu strategi intensif yang dikhususkan pada penetrasi pasar, pengembangan pasar, dan pengembangan produk.

\section{KESIMPULAN}

Analisis Bauran Pemasaran harus terus dilakukan, salah satunya adalah dengan didasarkan pada 4P (Product, Price, Promotion, Place) terhadap beras instan. Total skor internal sebesar 3,611549 dan faktor eksternal sebesar 3,110227, sehingga beras instan berada pada sel I yang menggambarkan bahwa keadaan Beras Instan pada saat ini sedang tumbuh dan membangun (Grow and build), yaitu beras instan berada pada tahap pengembangan produk. Hal tersebut didukung dengan adanya kemudahan beras instan dalam pengolahannya menjadi nasi, praktis dan sehat serta terus dilakukannya pengenalan-pengenalan beras instan kepada calon konsumen.

\section{UCAPAN TERIMAKASIH}

Ucapan terima kasih disampaikan kepada Kemenristek DIKTI atas dana penelitian Hibah Bersaing Tahun 2015, 2016 dan 2017 yang diterima Tim Peneliti sehingga penelitian berjudul Model Agroindustri Pangan Pokok Sumber Karbohidrat Sebagai Upaya Pencapaian Ketahanan, Keamanan dan Kedaulatan Pagan di Provinsi Bengkulu dapat terlaksaana. Artikel ini adalah sub bagian hasil penelitian yang dipublikasikan. 
Beras Instan<smiles>C[14CH2]</smiles>

Bauran Pemasaran

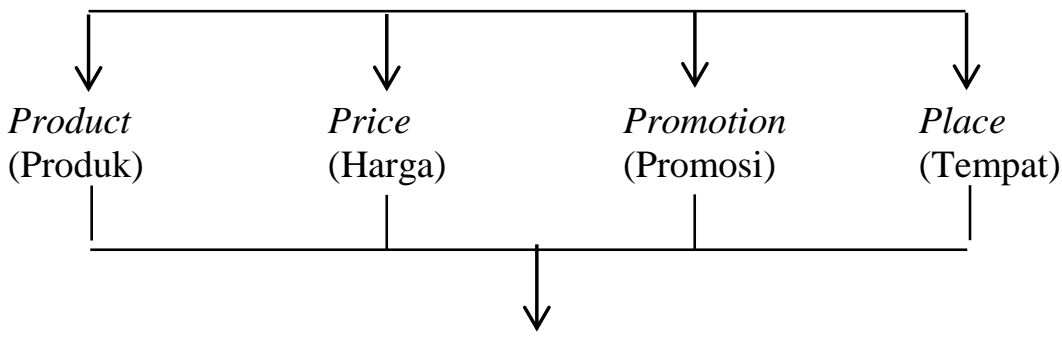

Posisi Beras Instan Pada Saat Ini

Sumber : data primer diolah, 2017

Gambar 1.

Kerangka Pemikiran

Tabel 1.

Matriks Evaluasi Faktor Internal Bauran Pemasaran Beras Instan di Kota Bengkulu.

\begin{tabular}{|c|c|c|c|c|c|}
\hline No & Atribut & Faktor Internal & Bobot & Rating & Skor \\
\hline \multirow[t]{8}{*}{1} & Produk & Rasa nasi & 0,08732 & 3,1 & 0,270704 \\
\hline & & Kepulenan nasi & 0,095775 & 3,4 & 0,325634 \\
\hline & & Aroma nasi & 0,090141 & 3,2 & 0,288451 \\
\hline & & Kemasan & 0,11831 & 4,2 & 0,496901 \\
\hline & & Volume & 0,092958 & 3,3 & 0,306761 \\
\hline & & Merek & 0,115493 & 4,1 & 0,473521 \\
\hline & & Makanan yang sehat dan aman bagi & & & \\
\hline & & $\begin{array}{l}\text { keluarga (tidak menggunakan bahan } \\
\text { pengawet dan } 100 \% \text { bahan asli) }\end{array}$ & 0,109859 & 3,9 & 0,428451 \\
\hline \multirow{4}{*}{$\begin{array}{l}2 \\
3 \\
4\end{array}$} & Harga & Keterjangkaun harga & 0,076056 & 2,7 & 0,205352 \\
\hline & Promosi & Praktis dan mudah disimpan & 0,112676 & 4,0 & 0,450704 \\
\hline & & Keterbatasan fasilitas pengenalan & & & \\
\hline & Tempat & $\begin{array}{l}\text { beras instan dilingkungan calon } \\
\text { konsume }\end{array}$ & 0,101408 & 3,6 & 0,36507 \\
\hline \multicolumn{2}{|c|}{ Jumlah } & & 1 & 35,5 & 3,611549 \\
\hline
\end{tabular}

Sumber : data primer diolah, 2017

Tabel 2.

Matriks Evaluasi Faktor Eksternal Bauran Pemasaran Beras Instan di Kota Bengkulu

\begin{tabular}{|c|c|c|c|c|c|}
\hline No & Atribut & Faktor Internal & Bobot & Rating & Skor \\
\hline \multirow[t]{3}{*}{1} & Produk & $\begin{array}{l}\text { Beras instan belum disukai oleh } \\
\text { calon konsumen }\end{array}$ & 0,215909 & 3,8 & 0,820455 \\
\hline & & $\begin{array}{l}\text { Beras instan kurang dibutuhkan } \\
\text { setiap saat }\end{array}$ & 0,147727 & 2,6 & 0,384091 \\
\hline & & $\begin{array}{l}\text { Keinginan calon konsumen untuk } \\
\text { mengganti beras Oryza sativa ke } \\
\text { beras instan }\end{array}$ & 0,102273 & 1,8 & 0,184091 \\
\hline 2 & Harga & $\begin{array}{l}\text { Banyak produk subtitusi yang } \\
\text { harganya lebih terjangkau }\end{array}$ & 0,142045 & 2,5 & 0,355114 \\
\hline 3 & Promosi & Promosi yang kurang gencar & 0,176136 & 3,1 & 0,546023 \\
\hline 4 & Tempat & $\begin{array}{l}\text { Kemudahan calon konsumen untuk } \\
\text { menjangkau keberadaan beras instan }\end{array}$ & 0,215909 & 3,8 & 0,820455 \\
\hline
\end{tabular}




\begin{tabular}{llll}
\hline Jumlah & 1 & 17,6 & 3,110227 \\
\hline Sumber : data primer diolah, 2017
\end{tabular}

TOTAL NILAI TERTIMBANG IFE $(3,611549)$

\begin{tabular}{|c|c|c|c|c|c|}
\hline \multirow{4}{*}{$\begin{array}{l}\text { Tinggi } \\
3,0-4,0\end{array}$} & $\begin{array}{cc} & \text { Kuat } \\
4,0 & (5, U-4, U)\end{array}$ & $\mathbf{3 , 0}$ & $\begin{array}{l}\text { Rata-rata } \\
(\mathcal{L}, \mathrm{U}-2, y y)\end{array}$ & 2,6 & $\begin{array}{l}\text { Lemah } \\
\left(1, U^{-1, y y)}\right.\end{array}$ \\
\hline & I & & II & & III \\
\hline & IV & & V & & VI \\
\hline & VII & & VIII & & IX \\
\hline
\end{tabular}

3,0

Gambar 2.

Matrik IE Bauran Pemasaran Beras Instan di Kota Bengkulu

\section{DAFTAR PUSTAKA}

Anonim. 2007. Matrik Internal Eksternal. JMT STMT Trisakti : 8 (2).

Asriani, Putri Suci dan Bonodikun. 2016. Model Agroindustri Pangan Pokok Sumber Karbohidrat Sebagai Upaya Pencapaian Ketahanan, Keamanan,

Dan Kedaulatan Pangan Di Provinsi

Bengkulu. Laporan Penelitian LPPM UNIB (tidak dipublikasikan).

David, Fred R. 2011. Manajemen Strategi.

Edisi 12. Salemba Empat, Jakarta.

Salastina, Ana. 2010. Strategi Pengembangan

Usaha Beras (Studi Kasus PB. Sugih

Mukti, Kabupaten Cianjur). Institut

Pertanian Bogor, Bogor.

www.repository.ipb.ac.id. [Didownload tanggal 19 Juni 2017]

Selmi, dkk. 2016. Strategi Pemasaran Madu

Di Kota Bengkulu. Universitas

Bengkulu, Bengkulu.

Sugiharta, Nyoman I, dkk. 2016. Strategi

Pemasaran Benih Padi pada UD Tani Sejati

di Kecamatan Blahbatuh Kabupaten Gianyar.

Jurnal Agribisnis dan Agrowisata : 5 (4) :

648-657 
Vol. 2, No. 2, Desember 2017: 291-357 AGRICORE-Jurnal Agribisnis dan Sosial Ekonomi Pertanian 